\title{
VOLUME XXXIV
}

\section{AUTHOR INDEX}

Author

BAKER, GARTH \& DOUGALIS, VASSILIOS A.

BRENT, RICHARD P. \& MCMILLAN, EDWIN M.

CHAR, BRUCE W.

CORMACK, G.

CRANDALL, MICHAEL G. \& MAJDA, ANDREW

DICKINSON, BRADLEY W.

DOUGALIS, VASSILIOS, A.

DUPONT, TODD \& SCOTT, RIDGWAY

ENGQUIST, BJORN \& OSHER, STANLEY

EVANS, JOHN W., GRAGG, WILLIAM B. \& LeVEQUE, RANDALL J.

FATUNLA, SIMEON OLA

FRANSÉN, ARNE \& WRIGGE, STAFFAN

GRAGG, WILLIAM B.

GUY, RICHARD K. \& SELFRIDGE, J. L.

HACKBUSCH, WOLFGANG

HILL, EDWARD JR.

JAMES, RODNEY

KARLSEN, LASSE $K$.

LeVEQUE, RANDALL J.

LYNCH, ROBERT E. \& RICE, JOHN R.

LYNESS, J. N. \& MONEGATO, G.

McMILLAN, EDWIN M.

MacLEAN, D. W.

MAJDA, ANDREW

MANTEUFFEL, T. A.

MARSAGLIA, GEORGE

MARTI, J. T.

MIEL, GEORGE J.

MINOLI, DANIEL

MINOLI, DANIEL
Tit/e

On the $L^{\infty}$-Convergence of Galerkin Approximations

for Second-Order Hyperbolic Equations.

Some New Algorithms for High-Precision Computation

of Euler's Constant.

On Stieltjes' Continued Fraction for the Gamma Function......547

See: WILLIAMS, H.C., CORMACK, G. \& SEAH, E................. 567

Monotone Difference Approximations for Scalar Conservation Laws.

Solution of Linear Equations With Rational Toeplitz Matrices.

See: BAKER, GARTH A. \& DOUGALIS, VASSILIOS A.......401

Polynomial Approximation of Functions in Sobolev Spaces.

Stable and Entropy Satisfying Approximations for

Transonic Flow Calculations.

On Least Squares Exponential Sum Approximation With Positive Coefficients.

Numerical Integrators for Stiff and Highly Oscillatory Differential Equations.

High-Precision Values of the Gamma Function and of Some Related Coefficients.

See: EVANS, JOHN W., GRAGG, WILLIAM B. \&

LEVEQUE, RANDALL J.

Corrigendum to "What Drives an Aliquot Sequence?".

Convergence of Multi-Grid Iterations Applied to Difference Equations

See: SHRAGER, RICHARD I. \& HILL, EDWARD JR

The Groups of Order $p^{6}$ ( $p$ an Odd Prime).

Computation of Steady Shocks by Second-Order FiniteDifference Schemes

See: EVANS, JOHN W., GRAGG, WILLIAM B. \& LeVEQUE, RANDALL J.

A High-Order Difference Method for Differential Equations.

Quadrature Error Functional Expansions for the Simplex When the Integrand Function Has Singularities at Vertices..

See: BRENT, RICHARD P. \& McMILLAN, EDWIN M.. .305

Residue Classes of the Partition Function.................................... 313

See: CRANDALL, MICHAEL G. \& MAJDA, ANDREW........ 1

An Incomplete Factorization Technique for Positive Definite Linear Systems.

Generating Random Variables With a $t$-Distribution

On the Convergence of an Algorithm Computing MinimumNorm Solutions of III-Posed Problems 521

Majorizing Sequences and Error Bounds for Iterative Methods.

Inductive Formulae for General Sum Operations.

Issues in Nonlinear Hyperperfect Numbers. .639 
Author

Title

MONEGATO, G. OSHER, STANLEY

PAIGE, C. C.

PARTER, SEYMOUR V.

PLESKEN, WILHELM \& POHST, MICHAEL

PLESKEN, WILHELM \& POHST, MICHAEL

PLESKEN, WILHELM \& POHST, MICHAEL

POHST, MICHAEL POHST, MICHAEL POHST, MICHAEL RICE, JOHN R. SALZER, HERBERT E.

SCHATZ, ALFRED H.

SCHONFELDER, J. L.

SCOTT, RIDGWAY

SEAH, E.

SELFRIDGE, J. L.

SHANNO, D. F.

SHRAGER, RICHARD I. \&

HILL, EDWARD JR.

STOKES, A. N.

TEMPLER, MARK

THOMÉE, VIDAR

TROESCH, B. A. WAGSTAFF, SAMUEL S. JR. WERSCHULZ, ARTHUR G.

WILLIAMS, H. C., CORMACK, G. \& SEAH, E. WINTHER, RAGNAR

WINTHER, RAGNAR WRIGGE, STAFFAN
See: LYNESS, J. N. \& MONEGATO, G. 213

See: ENGQUIST, BJORN\& OSHER, STANLEY .......................... 45

Error Analysis of Some Techniques for Updating Orthogonal Decompositions. 465

On the Roles of "Stability" and "Convergence" in Semidiscrete Projection Methods for Initial-Value Problems..... 127

On Maximal Finite Irreducible Subgroups of $G L(n, \mathrm{Z})$ III. The Nine Dimensional Case

On Maximal Finite Irreducible Subgroups of $G L(n, Z)$ IV. Remarks on Even Dimensions with Applications to $n=8$.... 259

On Maximal Finite Irreducible Subgroups of $G L(n, Z)$ V. The Eight Dimensional Case and a Complete Description of Dimensions Less Than Ten. 277

See: PLESKEN, WILHELM \& POHST, MICHAEL.................. 245

See: PLESKEN, WILHELM \& POHST, MICHAEL................... 259

See: PLESKEN, WILHELM \& POHST, MICHAEL................... 277

See: LYNCH, ROBERT E. \& RICE, JOHN R......................... 333

Misstatements in Milne-Thomson, Calculus of Finite Differences, Macmillan, London, 1933.

A Weak Discrete Maximum Principle and Stability of the Finite Element Method in $L_{\infty}$ on Plane Polygonal Domains.

Very High Accuracy Chebyshev Expansions for the Basic Trigonometric Functions.

See: DUPONT, TODD \& SCOTT, RIDGWAY............................ 441

See: WILLIAMS, H. C., CORMACK, G. \& SEAH, E............ 567

See: GUY, RICHARD K. \& SELFRIDGE, J. L....................... 319

On Variable-Metric Methods for Sparse Hessians......................... 499

Nonlinear Curve-Fitting in the $L_{1}$ and $L_{\infty}$ Norms..................... 529

A Stable Quotient-Difference Algorithm....................................515

On the Primality of $k !+1$ and $2 * 3 * 5 * \cdots * p+1 \ldots \ldots 303$

Negative Norm Estimates and Superconvergence in

Galerkin Methods for Parabolic Problems.............................. 93

The Shooting Method Applied to a Cyclic Inequality................ 175

p-Divisibility of Certain Sets of Bernoulli Numbers................... 647

Computational Complexity of One-Step Methods for Systems of Differential Equations....................................... 155

Calculation of the Regulator of a Pure Cubic Field.................. 567

A Conservative Finite Element Method for the Kortewegde Vries Equation. 23 Initial Value Methods for Parabolic Control Problems................115 See: FRANSÉN, ARNE \& WRIGGE, STAFFAN..................... 553 